DOI https://doi.org/10.30525/978-9934-26-148-0-32

\title{
ПОДАТКОВИЙ КОНТРОЛЬ: ПРОБЛЕМНІ ПИТАННЯ
}

\author{
Логвин А. В. \\ доктор філософії з права \\ м. Дніпро, Украӥна
}

У наукових колах по різному розглядають поняття податкового контролю. За позицією Кучерявенка М.П., податковий контроль є спеціальним державним контролем, який являє собою діяльність податкових органів та їх посадових осіб щодо перевірки виконання вимог податкового законодавства особами, які реалізують податкові зобов'язання або забезпечують їх виконання [1, с. 303-304].

В свою чергу, Корецький О.М. аналізуючи податковий контроль, зазначає, що він $є$ складовою державного фінансового контролю. Його сутність визначається комплексом заходів, що через уповноваження органів державного управління та делегування певних функцій податковим агентам мають забезпечити дотримання фізичними та юридичними особами податкового законодавства та норм податкового контролю, рішень за його наслідками [2].

За визначенням, яке міститься у Податковому кодексі [3], податковий контроль - система заходів, що вживаються контролюючими органами та координуються центральним органом виконавчої влади, що забезпечує формування та реалізує державну фінансову політику, 3 метою контролю правильності нарахування, повноти і своєчасності сплати податків і зборів, а також дотримання законодавства 3 питань регулювання обігу готівки, проведення розрахункових та касових операцій, патентування, ліцензування та іншого законодавства, контроль за дотриманням якого покладено на контролюючі органи.

Може здійснюватися шляхом проведення перевірок та звірок відповідно до вимог цього Кодексу, а також перевірок щодо дотримання законодавства, контроль за дотриманням якого покладено на контролюючі органи, у порядку, встановленому законами України, що регулюють відповідну сферу правовідносин. Також, передбачені види перевірок, які контролюючі органи (органи ДПС) мають право проводити, та до яких віднесено документальні (планові та/або позапланові; виїзні або невиїзні) перевірки. При цьому, документальні перевірки проводяться контролюючими органами в межах їх повноважень виключно у випадках (за наявності підстав) та у порядку, встановлених цим Кодексом. 
3 аналізу наведених положень можна дійти висновку, що податковий контроль $є$ одним 3 видів та/або складовою державного контролю. Завдання податкового контролю полягає у здійсненні податковими органами відповідних заходів, в тому числі шляхом призначення та проведення документальних позапланових перевірок, спрямованих на забезпечення дотримання суб'єктами господарювання правильності нарахування, повноти і своєчасності сплати податків і зборів. Тобто виключно Податковим кодексом визначається у який спосіб та за яких умов (підстав) контролюючими органами можуть проводитися відповідні контрольно-перевірочні заходи, зокрема, документальні позапланові перевірки.

Протягом 2020-2021 рр. в світі продовжуються відповідні заходи щодо запобігання виникненню і поширенню коронавірусної хвороби (COVID-19). У зв'язку з чим в Україні також вводились певні обмеження (запровадження карантину), які також вплинули на можливість проведення відповідними контролюючими органами контрольноперевірочних заходів (заборона або “мораторій” на проведення перевірок) [4] [5]. Зазначене, в свою чергу, торкнулось і проведення певних видів планових та позапланових документальних перевірок органами ДПС.

Однак, на початку 2021 року було здійснено зняття обмежень щодо проведення податковими органами певних видів перевірок (документальних планових та позапланових). Так, Постановою Кабінету Міністрів України від 03.02.2021 р. № 89 «Про скорочення строку дії обмеження в частині дії мораторію на проведення деяких видів перевірок» (далі за текстом - Постанова № 89) [6], яка набула чинності 09.02.2021 p., скасовано дію мораторію на окремі види податкових перевірок, але тільки стосовно юридичних осіб. Необхідність у прийнятті Поста-нови № 89 пояснюється тим, що дія мораторію на проведення перевірок триває з березня 2020 р., і тому органи ДПС позбавлені можливості реагувати на ризики несплати податків окремими платниками.

Разом 3 цим, залишається чинною норма Закону України Про внесення змін

до деяких законодавчих актів України, спрямованих на забезпечення додаткових соціальних та економічних гарантій у зв'язку з поширенням коронавірусної хвороби (COVID-19) [4] щодо мораторію на проведення документальних i фактичних податкових перевірок. Цей мораторій Законом України Про внесення змін до Податкового кодексу України та інших законів України щодо додаткової підтримки платників податків на період здійснення заходів, спрямованих на запобігання виникненню i 
поширенню коронавірусної хвороби (COVID-19) [5] продовжено по останній календарний день місяця (включно), у якому завершується дія карантину (пункт $52^{2}$ підрозділу 10 розділу ХХ Перехідні положення Податкового кодексу [3]).

Як бачимо наявність двох взаємно-протилежних положень нормативних актів, а саме Податкового кодексу (щодо наявності (продовження діï) мораторію) та Постанови № 89 (скасування мораторію), породжує певну правову колі-зію. В свою чергу, норми Податкового кодексу мають пріоритет над іншими нормативними актами, оскільки останній є спеціальним законом по відношенню до Постанови № 89, яка є виключно нормативно-правовим актом підзаконного характеру. Тобто, норми Податкового кодексу, як спеціального закону, мають найвищу юридичну силу. При цьому зміна положень Податкового кодексу можлива виключно на підставі внесення змін до нього на підставі відповідних законів.

Також, Постановою № 89 [6] разом із скороченням дій обмежень, в частині дій мораторію на проведення документальних (планових та позапланових перевірок) перевірок, дозволено проведення документальних позапланових перевірок суб'єктів господарювання реального сектору економіки, які сформували податковий кредит за рахунок оформлення ризикових операцій з придбання товарів/послуг (iз переліку ризикових платників податків, визначених у межах роботи Тимчасової слідчої комісії Верховної Ради України з питань розслідування оприлюднених у засобах масової інформації фактів можливих корупційних дій посадових осіб органів державної влади, які призвели до значних втрат дохідної частини Державного бюджету України, утвореної відповідно до Постанови Верховної Ради України від 24 квітня 2020 p. № 568-IX [7]). Разом 3 цим, на даний час наявний лише попередній звіт Тимчасової слідчої комісії Верховної Ради України (далі за текстом - ТСК ВР України) з питань розслідування оприлюднених у засобах масової інформації фактів можливих коруп-ційних дій посадових осіб органів державної влади, які призвели до значних втрат дохідної частини Державного бюджету України (далі за текстом - Звіт) [8]. Однак, у вказаному Звіті відсутні як перелік ризикових платників податків, визначених у межах роботи ТСК ВР України, так і згадування про його наявність. Відсутність офіційного оприлюдненого переліку ризикових платників податків, визначеного ТСК ВР України, призводить до неможливості виникнення правових підстав для призначення та проведення органами ДПС перевірок суб'єктів господарювання (платників податків) реального сектору економіки, навіть якщо при-пустити, що такий перелік (без офіційного його опри- 
люднення) все ж таки пере-даний ТСК ВР України до ДПС України. Більш того, відсутність такого переліку не дає права (можливості) для направлення запиту податковими органами в адресу платника податків 3 метою отримання пояснень та їх документального підтвердження.

Вищезазначене суперечливе нормативне регулювання Постановою № 89 питань здійснення податкового контролю, пов'язане як із скороченням строку дії обмеження в частині дії мораторію на проведення деяких видів перевірок, так і визначення підстав для призначення та проведення документальних позапланових перевірок, не сприяють юридичній визначеності у зазначених правовідно-синах між контролюючими органами та платниками податків.

Проведення податковим органом перевірки суб'єкта господарювання $\epsilon$ способом реалізації податковими органами владних управлінських функцій шляхом видання наказу про ii проведення в межах наданих законодавством повноважень, при цьому не дотримання порядку призначення та проведення перевірок призводить до порушення балансу публічних та приватних інтересів. На держав-ні органи покладено обов'язок запровадити внутрішні процедури, які посилять прозорість і ясність їхніх дій, мінімізують ризик помилок. Державні органи, які не впроваджують або не дотримуються своїх власних процедур, не повинні мати можливість отримувати вигоду від своїх протиправних дій або уникати виконання своїх обов'язків.

Доводиться констатувати, що прийняття Постанови № $89 є$ досить суперечливим. Існування нечіткого, суперечливого нормативного регулювання правовідносин між контролюючими органами та платниками податків порушує принцип правової визначеності. На наш погляд, як скорочення дій обмежень (мораторію) на можливість проведення органами ДПС певних видів перевірок, зокрема, доку-ментальних позапланових, так і визначення підстави для їх проведення наявність взаємовідносин суб' єктів господарювання реального сектору економіки 3 ризиковими платниками податків (за визначеним ТСК ВР України переліком (офіційно оприлюдненим)), необхідно було здійснити виключно шляхом внесення змін до Податкового кодексу України.

\section{Література:}

1. Кучерявенко М. П. Податкове право України : підручник / М.П. Кучерявенко, - Х.: Право, 2012. - 528 с.

2. Корецький О. М. Податковий контроль як складова державного фінансового контролю. Державне управління: удосконалення та розвиток. 2010. № 12. URL: http://www.dy.nayka.com.ua/?op=1\&z=403 (дата звернення 22.07.2021). 
3. Податковий кодекс України : Закон України від 02.12.2010 p. № 2755-VI. URL: https://zakon.rada.gov.ua/laws/show/2755-17\#Text (дата звернення 29.03.2021).

4. Про внесення змін до деяких законодавчих актів України, спрямованих на забезпечення додаткових соціальних та економічних гарантій у зв'язку з поширенням коронавірусної хвороби (COVID-19) : Закон України від 30.03.2020 p. № 540-IX. URL: https://zakon.rada.gov.ua/ laws/show/540-20\#n72 (дата звернення 07.07.2021).

5. Про внесення змін до Податкового кодексу України та інших законів України щодо додаткової підтримки платників податків на період здійснення заходів, спрямованих на запобігання виникненню і поширенню коронавірусної хвороби (COVID-19) : Закон України від 13.05.2020 р. № 591-IX. URL: https://zakon.rada.gov.ua/laws/show/ 591-20\#n20 (дата звернення 07.07.2021).

6. Про скорочення строку дії обмеження в частині дії мораторію на проведення деяких видів перевірок : Постанова Кабінету Міністрів України від 03.02.2021 p. № 89. URL: https://www.kmu.gov.ua/npas/proskorochennya-stroku-diyi-obmez-a89 (дата звернення 07.07.2021).

7. Про утворення Тимчасової слідчої комісії Верховної Ради України з питань розслідування оприлюднених у засобах масової інформації фактів можливих корупційних дій посадових осіб органів державної влади, які призвели до значних втрат дохідної частини Державного бюджету України. : Постанова Верховної Ради України від 24.04.2020 p. № 568-IX. URL: https://zakon.rada.gov.ua/laws/show/568IX\#Text (дата звернення 22.07.2021).

8. Про попередній звіт Тимчасової слідчої комісії Верховної Ради України з питань розслідування оприлюднених у засобах масової інформації фактів можливих корупційних дій посадових осіб органів державної влади, які призвели до значних втрат дохідної частини Державного бюджету України: Постанова Верховної Ради України від 02.12.2020 p. № 1034-IX. URL: https://zakon.rada.gov.ua/laws/show/103420\#Техt (дата звернення 22.07.2021). 